\title{
The effect of talent management on innovation: Evidence from Jordanian Banks
}

\author{
Raed Ibrahim Ibrahima ${ }^{* *}$ and Ghassan Issa AlOmari ${ }^{a}$
}

\begin{tabular}{l}
${ }^{a}$ Amman Arab University, Jordan \\
\hline C H R O N I C L E \\
\hline Article history: \\
Received: October 26, 2019 \\
Received in revised format: No- \\
vember 212019 \\
Accepted: November 23, 2019 \\
Available online: \\
November 23, 2019 \\
\hline Keywords: \\
Jordan \\
Talent Management \\
Banking Industry \\
Innovations
\end{tabular}

\begin{abstract}
A B S T R A C T
The concept of talent management has received great attention from scholars and practitioners. Despite this, there are few studies associated with the relationship between innovation and talent management. This study invokes human capital, McGregor's X and Y, social exchange and employee attraction theories to examine the link between talent management, product innovation, process innovation and marketing innovation. A questionnaire is developed to collect the data from the study sample consisted of (120) employees in top and middle management positions. Collated data is analyzed with variance-based structural equation modeling (PLS-SEM). Results from PLSSEM suggest that talent management had a significant and positive impact on product, process and marketing innovations. Supplemental ANOVA analyses also reveal that organizational tenure was a strong determinant for talent management as well as product, process and marketing innovations.
\end{abstract}

C 2020 by the authors; licensee Growing Science, Canada

\section{Introduction}

Nowadays, while traditional means of competitiveness such as technology and quality are easy to imitate and implement by competitors, there is an increase demand for a competent and highly knowledgeable employee base which can provide the flexibility needed for innovativeness and market as well as customer imperatives. In effect, the importance of "talent", "knowledge workers" and "competent employee" in today's knowledge-based society cannot be overemphasized. While it is getting easy for firms to imitate certain competitive process, the development of talent management remains a valuable and untapped opportunity for firms in the financial service industry. Strategic human resource management scholars all highlight the importance of internally consistent human resource practices as well as the alignment of or fit between an organizations strategy and its preferred human resource management practice. This is particularly important in today's knowledge based economy (Drucker, 2001). By implication, the banking sector strategy of innovativeness (process, product and market) can be duly sustained by implementing a knowledge-based human resource management practice to remain competitive. Talent management as a system of knowledge-based human resource management practice has a number of connotations both in practice and theory (Story, 2007). In its widest form it is concerned with identifying, developing, engaging/retaining, and deploying of "talent" in of particular organizational setting (CIPD, 2006). Talent management has also been described as a novel way of improving organizational innovativeness, accelerating career opportunities, handling succession planning; suggesting that it is first and foremost speaking of employees with great potentials (CIPD, 2006).

\footnotetext{
* Corresponding author.

E-mail address: raedibrahim@yahoo.com (R. I. Ibrahim) 


\section{Theoretical background and hypotheses development}

\subsection{Social exchange theory}

Most times, the target of the initiated actions mostly coworkers or subordinates take a commensurate response either good or bad to reciprocate the initiated action (Eisenberger et al., 1987; Gergen, 1969; Gouldner, 1960). Social exchange theory postulates that in responding to favorable actions, individuals will engage in a more positive or accommodating reciprocating response and/or lesser reciprocating responses in cases of negative initiated actions.

\subsection{McGregor's $X$ and $Y$ theory}

The core of McGregor's theory Y is the ideology that encourages reasonable laws that leads people towards achievement of goals rather than been propelled or forced into following the direction of an administration. The same ideology was echoed in Locke's work that suggests provision of freedom to pursue individualistic goal achievement as a basic right in organizations (Locke, 1690). Thus, the main proposition of theory $\mathrm{Y}$ is the provision of certain rights that will enable individuals to function with some degree of authority that gives the sense of power and control needed to satisfy their personal objectives in order to fulfil the organizational objectives. With regards to theory X, proponents believed that employees with such traits tend to be lethargic and dragging. Unlike their theory Y counterparts that are innovative and active, in theory X, individuals are passive and reactive. However, it has been noted that monetary incentives can motivate theory $\mathrm{X}$ individuals into better performance. Theory Y employees thrive under supervision and in collaborative societies as they often perceive supervisors as mentors that guide and improve them in the process and systems required to deliver optimally on the job. Contrarily, according to theory $\mathrm{X}$, employee performs better in isolated scenarios and settings.

\subsection{Human capital theory (relational and structural capital)}

Becker (1964) a proponent of human capital theory eluded that organizations that invest in educating and training of employees will have positive economic value due to the creation and development of skills and knowledge of the employees which in turn result in improved performance. According to Caner and Tyler (2013), firm's innovation capabilities is a function of the amount of the firms' investment in structural capital in terms of research and development expenditures, licenses and accreditations that organization holds and the number of patents the firm can boost of. Crema and Verbano (2016) in support for the view confirm a significant positive correlation exists between the level of innovation intensity in a firm and the amount of research and development investment of the firm.

\subsection{Employer attraction theory}

Employer attraction theory postulates that the right job applicants with right requisite skill set will only decide to seek employment in organizations which have demonstrated a reasonable degree of success at delivering superior benefits to their employees (Lievens \& Slaughter, 2016). Organizations may demonstrate this sort of success through their benefit packages to the existing employees and also through contract agreements with applicants (Baum \& Kabst, 2014).

\subsection{Talent management}

Talent management according to Scullion and Collings (2011) is the group of activities concerned with talent attraction, selection, development and retention of the finest employees in strategic organizational position. However, Iles et al. (2010) suggest that an organization's high-class should focus on high performers harms the morale of the other employees, and the organizations general performance ultimately. Thus, it is lucrative to employ a more inclusive talent management approach that entails the treatment of all employees as talent assets, that are actively engaged in organizational knowledge process.

\subsection{Innovation}

Research relating to the definition of innovation in the banking industry is limited. Summaries of innovation theories and related studies have been employed to give a picture of the definition of innovation in the banking industry (Yen, 2013). Consequently, innovation in the banking industry has been loosely described as the software or hardware application, services, processes, products or ideas that are seen as new by the adopting unit or organization. It has also been said to be the activities that reduces risks and costs internally for the banks or create more convenience and meet the demands of customers (Bos, Kolari, \& van Lamoen, 2012). It is worthy of note that only a limited number of academic studies have investigated innovation in the banking industry. Most of the available studies investigated individual innovative activities and products, in addition to discussing performance, orientations and developments. Studies focused on innovative activities and products from the perspective of the banking industry are rare (Yen, 2013). A summary of studies on the management of innovation in banks was published by Tipu (2011). His summary included a number of studies on the types of innovation, measures of innovation, protection of innovation, factors affecting innovation and process of innovation. The organizational structure of product in- 
novation in the banking sector has been analyzed and reported in terms of stratification, centralization, specialization, standardization and formalization (Johne \& Harbourne, 1985). Innovations in the banking industry have been generally categorized into (1) new products (such as adjustable-rate mortgages, credit and debit cards, automated teller machines or ATMs, etc.), (2) new processes (such as, securitization of loans, automated credit scoring models, electronic payments and record keeping, etc.) and (3) new organizational arms, practices or forms (e.g., diversified banks with traditional and nontraditional financial services, interstate banking organizations, etc.). The actual importance of these innovations is in what they contribute to the enrichment of financial intermediation; a process which ensures that savings are allocated to investment in so doing contributing to the growth of the economic (Bos et al., 2012).

\subsection{Talent management and product innovation}

When firm strives to attain competitive advantage, the intensity of the competition nowadays has made it almost impossible to maintain or retain it. Also, most new products and business models are characterized with short life cycle thus also creating a demand for continuous innovation in the firm. Further, organizations willing to tackle the menace of changing global demands must substitute problem-oriented business approach with vision-oriented ones. To successfully tackle these issues and also to be able to innovate continuously as the demand of today's business requires, firms must implement viable talent management systems. As argued by Tarique and Schuler (2010) organizations can only succeed by sustaining their businesses through people. The talent management systems in firms is known for their ability to position the firm as strong employer brand that has choice in employee acquisition based on their value proposition (Morley et al., 2015; Sparrow \& Makram, 2015; Tatoglu et al., 2016). When viewed in the light of social exchange theory, implementation of adequate talent management system in banks will elicit the employees to return to the value received from their organization to give their best for the organization. This often includes involvement in creation of innovative products and engagement to the firm. To fill the theoretical and empirical void in the literature, this study argued that human capital theory when integrated with McGregor's X and Y, and social exchange theory could translate work attitudes to employer attraction and interpret employee attraction from employee perspective. Building on this link, employer attraction theory explains why such symbiotic relationship could manifest greater innovation (Sivertzen et al., 2013). Thus, the next hypothesis is proposed as:

Hypothesis 1a. Talent management will have positive and significant impact on product innovation.

\subsection{Talent management and process innovation}

As opined by Kucherov and Zavyalova (2012), managers and leaders of successful organizations depend on the deployment of talent to achieve their business goals. They further highlighted emotional maturity, functional skills, communicative skills, ability to deliver results, sharp strategic minds, entrepreneurial instincts and ability to attract and inspire other talents as the main qualities of a talented individual within an organization (Lewis \& Heckman, 2006). In Rotolo et al.'s (2018) view, exceptional abilities to be successful in a wide range of activities are distinguishing factors for a talent individual. As firms take up the challenge of strategic talent management by systematically positioning key individuals to positions that will lead to sustainable competitive advantage, such talent begins to contribute to the knowledge base of the firm as well as the standard operation process of the firm. In their studies on innovation in Jordanian banks, Abou-Moghli et al. (2012) reported that process innovations in banks have a huge positive impact on lead time as well as the time required to improve on existing services and products, or to develop new ones. They also added that the time required in attending to customers or delivery time is likewise shortened by process innovation. Based on the tenets of employer attraction theory which postulates that organizations that create positive perception of commitment to greater employee benefits will attract the best talent and human capital theory which argues that the investment in human capital is a propeller of organization success through development of knowledge infrastructure in its human capital, it can be argued that talented employees within an organization that uphold such views will feel obligated to reciprocate the benefits received from their organizations by striving to develop new routines, competencies and capabilities for the organization to deliver optimally to their customers. Hence, the following hypothesis is proposed:

Hypothesis $1 \mathrm{~b}$. Talent management will have positive and significant impact on process innovation.

\subsection{Talent management and marketing innovation}

According to Kiiyuru (2014), organizations with market innovativeness strive to recognize and take advantage of new opportunities for delivering value to the market a head of their competition. To achieve this, firms sometimes segment the market and entrust responsibilities of managing specific market segments to individual talents within their establishment thereby creating both challenge and opportunity for resource maximization. Further investigation reveals that market innovation contributes immensely to firm performance in the banking context. In addition, there is a significant connection between talent management and market innovation of the firms. This is possible because talent management utilize the knowledge, capabilities and other resources of the talents in the organization to sense and seize new market opportunities. With proper talent management systems, firms can deploy talents to manage and deliver results for every singular opportunity identified in the 
market through value creation via pricing, vigorous anti-competitors marketing promotions, swift reaction to changes, analysis of the market environment, and accessibility to unique capabilities and resources. Thus, the third hypothesis is proposed as:

Hypothesis 1c. Talent management will have positive and significant impact on marketing innovation.

Prior research has shown that demographic variables often exert significant impact on work-related variables such as talent management, product innovation, process innovation and marketing innovation. Based on the extant claims and the aforementioned literature review, the following hypotheses are proposed:

Hypothesis 2. Talent management (i.e., talent attraction, talent training, talent development and talent retention) varies across demographic variables (i.e., gender, age, education, organizational tenure, and bank type (i.e., commercial and Islamic)).

Hypothesis 3. Innovation (i.e., product innovation, process innovation and marketing innovation) varies across demographic variables (i.e., gender, age, education, organizational tenure, and bank type (i.e., commercial and Islamic)).

The study model is presented in Fig. 1.

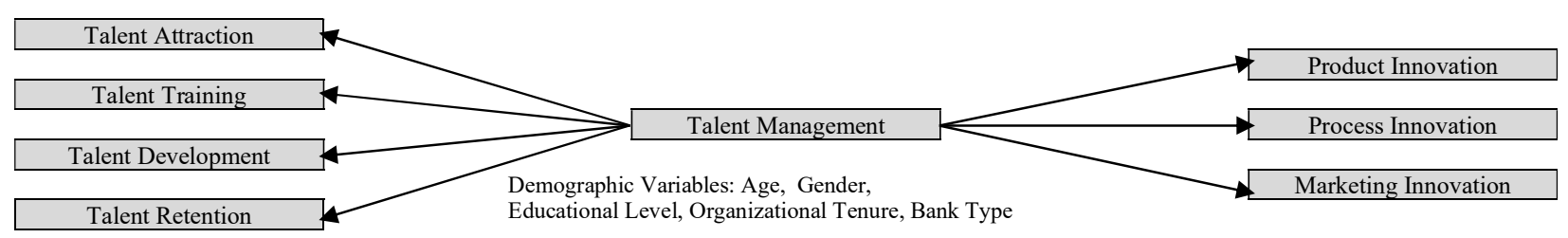

Fig. 1. Study model

\section{Research methodology}

This study opts for positivist research philosophy which is mostly conducted via survey. Therefore, the researchers adopted and modify existing scale items from previous studies, because most of the existing studies were conducted in Western and affluent nations, the scale items happened to be in English. The official language of Jordan is Arabic, and employees widely speak and understand Arabic, Following Perrewe et al. (2002) approach, the developed questionnaire was back-translated to Arabic and to English by independent translators.

As a next step, the researcher conducted a pre-test (pilot) study to evaluate the appropriateness, clarity, and also assess the presence of ambiguity associated with wordings and sentence structure. Applicable in previous empirical studies, the participants were briefed about the aim, objectives and the intent of the research. To evade error variance the researchers made a short demonstration on how the participant should code or respond to the survey questions. Additionally, "anonymity and confidentiality of the respondents was assured, which in turn diminish social desirability bias. This is a process use by researchers to mitigate the threat of common method bias" as noted by (MacKenzie et al., 2011; Podsakoff et al., 2012).

To realize the purpose of the study, the researchers collected the data from the (6) Jordanian (commercial and Islamic) banks which agreed to participate in the study. To propel the veracity and predictability of the study, in particular to enhance the high reliability and validity of the study outcome a complete census was deployed and (145) employees in top and middle management level voluntary participated in the study. More specifically, the researchers distributed (145) survey packets and (120) valid surveys were obtained due to erroneous reports and missing information.

The questionnaire used for data collection in this study comprised of two distinct sections. Section one presents demographic variables of the participants and their employing organizations. Section one presents items for the variable of interest, more specifically, variables used in the study namely: Talent management, product innovation, process innovation and marketing innovation. Instrument scale was anchored on a 5-point rating scale spanning from $(1=$ strongly disagree to $5=$ strongly agree). Higher points closer to 5, denotes bank's management emphasis on talent management and/or innovation.

\subsection{Demographic information}

The demographic variables included are gender, age, educational level, organizational tenure (work experience) and type of bank (See Table 2 for detailed information). 
Table 1

Demographic characteristics of the sample

\begin{tabular}{|c|c|c|c|}
\hline \multicolumn{2}{|l|}{ Demographics } & Number & $\%$ \\
\hline \multirow{2}{*}{ Gender } & Male & 92 & 76.7 \\
\hline & Female & 28 & 23.3 \\
\hline \multirow{6}{*}{ Age } & 25 to less than 30 & 1 & 0.8 \\
\hline & 30 to less than 35 & 55 & 45.8 \\
\hline & 35 to less than 40 & 12 & 10.0 \\
\hline & 40 to less than 45 & 15 & 12.5 \\
\hline & 45 to less than 50 & 37 & 30.8 \\
\hline & 50 and above & 0 & 0.0 \\
\hline \multirow{4}{*}{ Education } & High School & 0 & 0.0 \\
\hline & Bachelor's Degree & 91 & 75.8 \\
\hline & Master's Degree & 27 & 22.5 \\
\hline & $\mathrm{PhD}$ & 2 & 1.7 \\
\hline \multirow{4}{*}{ Organizational Tenure } & Less than 5 years & 0 & 0.0 \\
\hline & 5 years to less than 10 years & 23 & 19.2 \\
\hline & 10 years to less than 15 years & 89 & 74.2 \\
\hline & 15 years and above & 8 & 6.7 \\
\hline \multirow{2}{*}{ Type of Bank } & Commercial Banks & 56 & 46.7 \\
\hline & Islamic Banks & 64 & 53.3 \\
\hline $\mathrm{N}$ & & \multicolumn{2}{|c|}{120} \\
\hline
\end{tabular}

Talent management - was operationalized with a second-order construct that comprise of four (4) first-order constructs namely; talent attraction four (4) items, talent training six (6) items, talent development five (5) items and talent retention eleven (11) items utilized in study (Jayaraman et al., 2018).

Product and process innovation - were operationalized with thirteen (13) items utilized by prior researchers (Elrehail et al., 2018; Škerlavaj et al., 2010).

Marketing innovation - was operationalized with a seven (7) items scale widely used by scholars in the West and Eastern part of the world (Aksoy, 2017; Deshpandé et al., 1993; Sok et al., 2013).

\section{Data analysis techniques}

Applicable to most empirical studies, especially quantitative ones, data analyses were operationalized and deployed to achieve the objectives of this study. First, to understand the demographic breakdown and distribution of the participants in the study; a frequency analysis was carried out in SPSS version 25. Secondly, the researchers used SmartPLS version 3 to evaluate the theoretical pattern of the observational factors under investigation. This was materialized with the availability of weights from the factors such as standardized factor loadings (SFL), t-statistics, mean and standard deviation. The researchers then assessed the convergent and divergent validity of the model's variables and the reliability and internal consistencies. The researchers gauged this metrics by assessing Cronbach's alpha $(\alpha)$, composite reliability (CR), and average variance extracted (AVE).

Furthermore, the linearity of the variables under investigation was assessed through correlation coefficient. To do this, Pearson correlation analysis was conducted, the coefficient ( $\mathrm{r}$ ) was evaluated alongside its $\mathrm{p}$-value, this allowed the researchers to diagnose the strength, significance, and directions of the relationship between the variables of interest. Last but not the least, the direct relationships were evaluated with structural equation modeling technique in SmartPLS. Supplementary analysis was conducted to gauge the effect of the demographic variables on the variables under investigation. To achieve this, Analysis of Variance (ANOVA) was utilized; ANOVA "is a collection of statistical models and their associated estimation procedures used to analyze the differences among group means in a sample".

\section{Data analysis and results}

\subsection{Reliability and validity}

To evaluate the reliability and convergent validity of the measures in this investigation, the researchers assessed the outer model [Cronbach's Alpha $(\alpha)$, Rho, average variance extracted (AVE), and composite reliability (CR)]. Cronbach's Alpha, Rho, CR, and AVE estimates were also above the cut-off point, for instance, $\alpha$, Rho and CR values were all above .70. Similarly, the value of AVE was also above the .50 except that of talent management. Despite this shortcoming, we can still assume convergent validity as Fornell and Larcker's (1981) have argued that if AVE value is less than .50; and CR value is above .70 there is some evidence of convergent validity (Hair et al., 2013). These indicators are presented in Table 2. 
Table 2

Reliability, convergent and divergent validity of research instruments

\begin{tabular}{llllll}
\hline & Variables & $\alpha$ & rho_A & CR & \\
\hline 1 & Talent Management & .90 & .91 & .92 & .30 \\
2 & Product Innovation & .87 & .88 & .90 \\
3 & Process Innovation & .72 & .72 & .83 \\
4 & Marketing Innovation & .88 & .89 & .91 \\
\hline
\end{tabular}

Note: $\alpha$ Cronbach's Alpha; rho_A, Rho_A reliability coefficient; CR, composite reliability; AVE, average variance extracted

Additionally, the factor loadings are presented in Fig. 3. In sum, the extant evidence suggests evidence of convergent validity with the utilized measures. The other dimension of construct validity is the discriminant validity. The researchers utilized Fornell and Larcker's (1981) approach and Heterotrait-Monotrait (HTMT) ratio of correlations (Henseler et al., 2015) to assess discriminant and divergent validity. Table 3 (in the appendix) shows that the square root of AVE values for each construct is greater than its correlation coefficients with other constructs, which satisfies Fornell-Larcker criterion. Table 4 (in the appendix) shows that the HTMT values fulfilled the condition of HTMT.90 (Kline, 2015). Overall, these results in Table 3 and 4 assert evidences of divergent / discriminant validity.

Table 3

Fornel-Larcker Criterion

\begin{tabular}{llllll}
\hline & Variables & 1 & 2 & 3 & 4 \\
\hline 1 & Talent Management & .55 & - & & \\
2 & Product Innovation & .69 & .72 & - & - \\
3 & Process Innovation & .70 & .58 & .74 & .77 \\
4 & Marketing Innovation & .71 & .47 & .52 & .77 \\
\hline
\end{tabular}

\section{Table 4}

Heterotrait-Monotrait Ratio (HTMT)

\begin{tabular}{llllll}
\hline & Variables & 1 & 2 & 3 & 4 \\
\hline 1 & Talent Management & - & & & \\
2 & Product Innovation & .76 & - & & \\
3 & Process Innovation & .84 & .73 & - & - \\
4 & Marketing Innovation & .77 & .53 & .64 & \\
\hline
\end{tabular}

\subsection{Correlation and descriptive statistics}

Table 5 presents correlation coefficients of the study variables and several demographic variables, the outcome in the table shows strong evidence of interdependence among the variables. The correlativity between talent management and product innovation is positive and significant $(r=.672, \rho=.000)$. Similarly, talent management has a significant and positive correlativity with process innovation $(\mathrm{r}=.681, \rho=.000)$ and marketing innovation $(\mathrm{r}=.683, \rho=.000)$. This provides preliminary support for the hypothesized relationships. In addition, the aggregate score of each variable (mean) and the standard deviations are also reported in Table 5 as follows.

Table 5

Correlations, means and standard deviations

\begin{tabular}{|c|c|c|c|c|c|c|c|c|c|c|c|}
\hline & Variables & $\mathrm{M}(\mathrm{SD})$ & 1 & 2 & 3 & 4 & 5 & 6 & 7 & 8 & \\
\hline 1 & Gender & $1.23(.42)$ & - & & & & & & & & \\
\hline 2 & Age & $3.27(1.34)$ & $.658^{* *}$ & - & & & & & & & \\
\hline 3 & Educational Level & $2.26(.48)$ & $.946^{* *}$ & $.602^{* *}$ & - & & & & & & \\
\hline 4 & Tenure & $2.88(.49)$ & .020 & .038 & -.004 & - & & & & & \\
\hline 5 & Bank Type & $1.53(.50)$ & -.037 & -.164 & -.054 & -.136 & - & & & & \\
\hline 6 & Talent Management & $3.92(.41)$ & -.177 & -.010 & -.147 & .078 & .018 & - & & & \\
\hline 7 & Product Innovation & $4.14(.50)$ & -.077 & .039 & -.049 & -.054 & -.088 & $.672^{* *}$ & - & & \\
\hline 8 & Process Innovation & $4.29(.43)$ & -.104 & -.036 & -.078 & .076 & .080 & $.681^{* *}$ & $.589^{* *}$ & - & \\
\hline 9 & Marketing Innovation & $3.93(.50)$ & .003 & .010 & .015 & .088 & .173 & $.683^{* *}$ & $.476^{* *}$ & $.513^{* *}$ & - \\
\hline
\end{tabular}

Note: M, mean, SD, standard

** Correlation is significant at the 0.01 level (2-tailed).

\subsection{Hypothesis testing - structural equation modeling}

To test the proposed hypotheses, the researchers utilized SmartPLS version 3.2.7. As a structural equation software designed based on partial least squares also known as variance based-SEM (PLS-SEM), SmartPLS has gained momentum in the last 10 years (Richter et al., 2016). The obtained data was analyzed with SmartPLS software, the outcomes are presented in two folds: Fig. 2 and Fig. 3. In Fig. 2, outer model weights represent the factor loadings of each item, the inner model weights represent the direct effects (beta value) and R-Squares are displayed inside the circles. A bootstrapping analysis with 2,000 sub-samples for further analysis was conducted to obtain the significant levels of the results obtained in Fig. 2. Fig. 3 presents 
the respective T-statistics of beta estimates and factor loadings presented in Fig. 2. Hypothesis 1a predicted that talent management will have a positive and significant effect on product innovation. The outcome revealed that the beta and $t-v a l u e(\beta$ $=.692, \mathrm{t}=12.335, \rho=.000)$ in Fig. 2 and Fig. 3 are statistically significant. Rendering support to the initial proposition, that is talent management influences product innovation. More specifically, the results denote that 1.000 units increase in talent management will result to 0.692 units increase in product innovation. Hypothesis $1 \mathrm{~b}$ predicted that talent management would have a positive and significant effect on process innovation. The outcome revealed that the beta and $\mathrm{t}$-value $(\beta=.695, \mathrm{t}=$ 14.337, $\rho=.000)$ in Fig. 2 and Fig. 3 are statistically significant. Rendering support to the initial proposition, that is talent management influences process innovation. More specifically, the results denote that 1.000 units increase in talent management will result to 0.695 units increase in process innovation. Hypothesis 1c predicted that talent management will have a positive and significant effect on marketing innovation. The outcome revealed that the beta and $\mathrm{t}$-value $(\beta=.706, \mathrm{t}=14.282$, $\rho=.000$ ) in Fig. 2 and Fig. 3 are statistically significant. Rendering support to the initial proposition, that is talent management influences marketing innovation. More specifically, the presents outcome denote that 1.000 units increase in talent management will result to 0.706 units increase in marketing innovation.

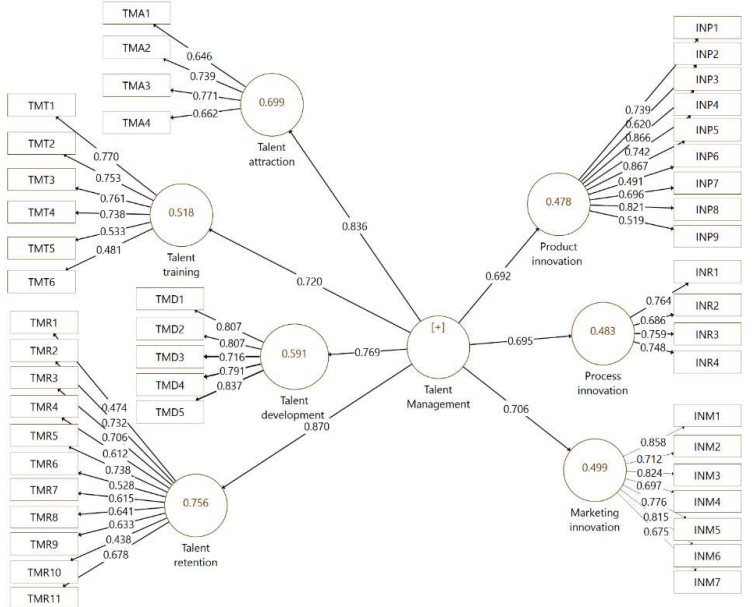

Fig. 2. Measurement model with factor loadings

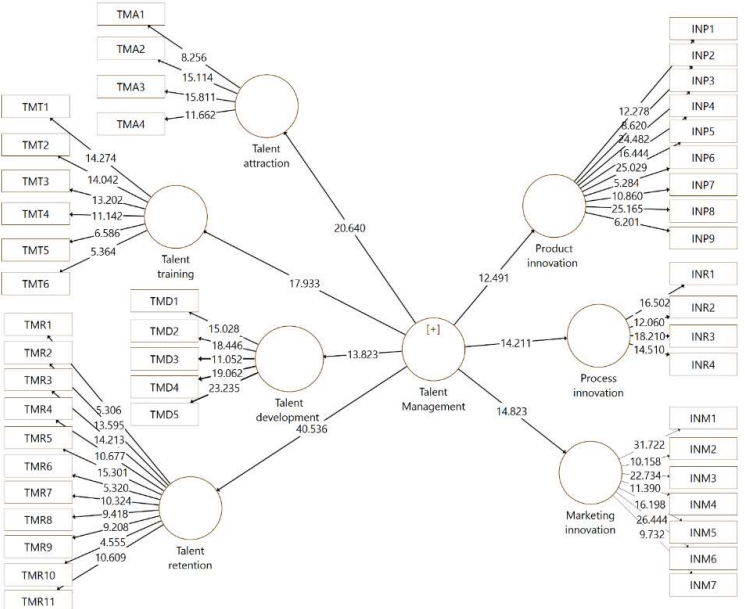

Fig. 3. Measurement model with effects size (t-value)

\subsection{Supplementary analysis (ANOVA)}

Hypothesis 2 predicted that the perception of talent management will differ across several demographic variables (i.e., gender, age, education, organizational tenure, and bank type). To observe the presence of variance in the perceptions, this study employed ANOVA in SPSS. A post hoc comparisons using Tukey test indicated that the mean score across gender, age groups, educational level and bank type did not differ significantly on talent management perception. However, this study uncovers that organizational tenure varies across talent management perception. More specifically, a post hoc comparisons using the Tukey HSD test indicated that the mean score for those with organizational tenure of (10) years to less than 15 years were significantly different to those with organizational tenure of 5 years to less than 10 years and 15 years and above. See Table 6 for details.

Table 6

ANOVA for talent management and demographics information

\begin{tabular}{|c|c|c|c|c|}
\hline Demographics & & $\mathrm{N}$ & $\mathrm{M}(\mathrm{SD})$ & F-statistics \\
\hline \multirow{2}{*}{ Gender } & Male & 92 & $3.96(.41)$ & \multirow{2}{*}[F(1,118)=3.831,\rho=.053]{} \\
\hline & Female & 28 & $3.79(.41)$ & \\
\hline \multirow{6}{*}{ Age } & 25 to less than 30 & 1 & $4.15(.00)$ & \multirow{6}{*}[F(4,115)=.170,\rho=.953]{} \\
\hline & 30 to less than 35 & 55 & $3.91(.40)$ & \\
\hline & 35 to less than 40 & 12 & $3.95(.49)$ & \\
\hline & 40 to less than 45 & 15 & $3.97(.42)$ & \\
\hline & 45 to less than 50 & 37 & $3.90(.42)$ & \\
\hline & 50 and above & 0 & $0.00(.00)$ & \\
\hline \multirow{4}{*}{ Education } & High School & 0 & $0.00(.00)$ & \multirow{4}{*}[F(2,117)=1.347,\rho=.264]{} \\
\hline & Bachelor's Degree & 91 & $3.96(.41)$ & \\
\hline & Master's Degree & 27 & $3.81(.42)$ & \\
\hline & $\mathrm{PhD}$ & 2 & $3.79(.52)$ & \\
\hline \multirow{4}{*}{ Tenure } & Less than 5 years & 0 & $0.00(.00)$ & \multirow{4}{*}[F(2,117)=10.481,\rho=.000]{} \\
\hline & 5 to less than 10 years & 23 & $3.72(.41)$ & \\
\hline & 10 to less than 15 years & 89 & $4.01(.36)$ & \\
\hline & 15 years and above & 8 & $3.53(.54)$ & \\
\hline \multirow{2}{*}{ Type of Bank } & Commercial Banks & 56 & $3.91(.38)$ & \multirow{2}{*}[F(1,118)=.038,\rho=.846]{} \\
\hline & Islamic Banks & 64 & $3.92(.48)$ & \\
\hline
\end{tabular}

Note: N, Sample; M, Sample Mean; SD, Standard Deviation; F, F-Statistics; $\rho$, significance level 
Hypothesis 3 predicted that product innovation, process innovation and marketing innovation will differ across several demographic variables (i.e., gender, age, education, organizational tenure, number of employees in the organization, and bank type). To observe the presence of variance in the perceptions, this study employed ANOVA in SPSS. This study considers three types of innovations, as such, the researchers will analyze the variance in 3-folds. See Tables 7, 8 and 9 for details.

\section{Table 7}

ANOVA for product innovation and demographics information

\begin{tabular}{|c|c|c|c|c|}
\hline Demographics & & $\mathrm{N}$ & $\mathrm{M}(\mathrm{SD})$ & F-statistics \\
\hline \multirow{2}{*}{ Gender } & Male & 92 & $4.18(.51)$ & \multirow{2}{*}[\mathrm{F}(1,118)=.702,\rho=.404]{} \\
\hline & Female & 28 & $4.07(.49)$ & \\
\hline \multirow{6}{*}{ Age } & 25 to less than 30 & 1 & $4.89(.00)$ & \multirow{6}{*}[\mathrm{F}(4,115)=.834,\rho=.506]{} \\
\hline & 30 to less than 35 & 55 & $4.11(.51)$ & \\
\hline & 35 to less than 40 & 12 & $4.06(.58)$ & \\
\hline & 40 to less than 45 & 15 & $4.24(.47)$ & \\
\hline & 45 to less than 50 & 37 & $4.16(.48)$ & \\
\hline & 50 and above & 0 & $0.00(.00)$ & \\
\hline \multirow{4}{*}{ Education } & High School & 0 & $0.00(.00)$ & \multirow{4}{*}[F(2,117)=.156,\rho=.856]{} \\
\hline & Bachelor's Degree & 91 & $4.16(.51)$ & \\
\hline & Master's Degree & 27 & $4.10(.47)$ & \\
\hline & $\mathrm{PhD}$ & 2 & $4.11(1.1)$ & \\
\hline \multirow{4}{*}{ Tenure } & Less than 5 years & 0 & $0.00(.00)$ & \multirow{4}{*}[F(2,117)=6.77,\rho=.002]{} \\
\hline & 5 to less than 10 years & 23 & 4.03(.53) & \\
\hline & 10 to less than 15 years & 89 & $4.22(.45)$ & \\
\hline & 15 years and above & 8 & $3.61(.65)$ & \\
\hline \multirow{2}{*}{ Type of Bank } & Commercial Banks & 56 & $4.19(.47)$ & \multirow{2}{*}[\mathrm{F}(1,118)=.916,\rho=.341]{} \\
\hline & Islamic Banks & 64 & $4.10(.53)$ & \\
\hline
\end{tabular}

Note: N, Sample; M, Sample Mean; SD, Standard Deviation; F, F-Statistics; $\rho$, significance level

Table 8

ANOVA for process innovation and demographics information

\begin{tabular}{|c|c|c|c|c|}
\hline Demographics & & $\mathrm{N}$ & $\mathrm{M}(\mathrm{SD})$ & F-statistics \\
\hline \multirow{2}{*}{ Gender } & Male & 92 & $4.32(.43)$ & \multirow{2}{*}[F(1,118)=1.30,\rho=.256]{} \\
\hline & Female & 28 & $4.21(.44)$ & \\
\hline \multirow{6}{*}{ Age } & 25 to less than 30 & 1 & $4.75(.00)$ & \multirow{6}{*}[F(4,115)=.515,\rho=.725]{} \\
\hline & 30 to less than 35 & 55 & $4.29(.41)$ & \\
\hline & 35 to less than 40 & 12 & $4.40(.48)$ & \\
\hline & 40 to less than 45 & 15 & $4.23(.47)$ & \\
\hline & 45 to less than 50 & 37 & $4.28(.44)$ & \\
\hline & 50 and above & 0 & $0.00(.00)$ & \\
\hline \multirow{4}{*}{ Education } & High School & 0 & $0.00(.00)$ & \multirow{4}{*}[F(2,117)=.405,\rho=.668]{} \\
\hline & Bachelor's Degree & 91 & $4.32(.43)$ & \\
\hline & Master's Degree & 27 & $4.23(.44)$ & \\
\hline & $\mathrm{PhD}$ & 2 & $4.25(.71)$ & \\
\hline \multirow{4}{*}{ Tenure } & Less than 5 years & 0 & $0.00(.00)$ & \multirow{4}{*}[F(2,117)=6.86,\rho=.002]{} \\
\hline & 5 to less than 10 years & 23 & $4.10(.40)$ & \\
\hline & 10 to less than 15 years & 89 & $4.37(.41)$ & \\
\hline & 15 years and above & 8 & $3.97(.50)$ & \\
\hline \multirow{2}{*}{ Type of Bank } & Commercial Banks & 56 & $4.26(.43)$ & \multirow{2}{*}[F(1,118)=.763,\rho=.384]{} \\
\hline & Islamic Banks & 64 & $4.33(.44)$ & \\
\hline
\end{tabular}

Note: N, Sample; M, Sample Mean; SD, Standard Deviation; F, F-Statistics; $\rho$, significance level

In fold 1, $2 \& 3$ this study gauges the variance for product, process and marketing innovations across the demographic variables. Results from one-way ANOVA indicated that the mean score across gender, age groups, educational level and bank type did not differ significantly on product, process and marketing innovations. However, organizational tenure differs significantly on product, process and marketing innovations, thus, a post hoc comparisons using the Tukey HSD test indicated that the mean score for those with organizational tenure of 10 years to less than 15 years was significantly different than those with organizational tenure of 5 years to less than 10 years and 15 years and above. These results have indicated that work experience is an important determinant for product, process and marketing innovations, but as the tenure increases a decline in product, process and marketing innovations are experienced in the banking industry. Based on the outcome in the aforementioned folds, hypothesis 3 received partial empirical support since product, process and marketing innovations have significant associations with organizational tenure in fold $1,2 \& 3$ analysis. 
Table 9

ANOVA for marketing innovation and demographics information

\begin{tabular}{|c|c|c|c|c|}
\hline Demographics & & $\mathrm{N}$ & $\mathrm{M}(\mathrm{SD})$ & F-statistics \\
\hline \multirow{2}{*}{ Gender } & Male & 92 & $3.92(.48)$ & \multirow{2}{*}[F(1,118)=.001,\rho=.977]{} \\
\hline & Female & 28 & $3.93(.57)$ & \\
\hline \multirow{6}{*}{ Age } & 25 to less than 30 & 1 & $4.86(.00)$ & \multirow{6}{*}[F(4,115)=.938,\rho=.445]{} \\
\hline & 30 to less than 35 & 55 & $3.91(.48)$ & \\
\hline & 35 to less than 40 & 12 & $3.87(.47)$ & \\
\hline & 40 to less than 45 & 15 & $3.93(.55)$ & \\
\hline & 45 to less than 50 & 37 & $3.95(.51)$ & \\
\hline & 50 and above & 0 & $0.00(.00)$ & \\
\hline \multirow{4}{*}{ Education } & High School & 0 & $0.00(.00)$ & \multirow{4}{*}[F(2,117)=.085,\rho=.919]{} \\
\hline & Bachelor's Degree & 91 & $3.92(.48)$ & \\
\hline & Master's Degree & 27 & $3.92(.54)$ & \\
\hline & $\mathrm{PhD}$ & 2 & $4.07(1.11)$ & \\
\hline \multirow{4}{*}{ Tenure } & Less than 5 years & 0 & $0.00(.00)$ & \multirow{4}{*}[F(2,117)=3.96,\rho=.022]{} \\
\hline & 5 to less than 10 years & 23 & $3.73(.42)$ & \\
\hline & 10 to less than 15 years & 89 & $4.00(.49)$ & \\
\hline & 15 years and above & 8 & $3.68(.67)$ & \\
\hline \multirow{2}{*}{ Type of Bank } & Commercial Banks & 56 & $3.83(.48)$ & \multirow{2}{*}[F(1,118)=3.62,\rho=.059]{} \\
\hline & Islamic Banks & 64 & $4.01(.51)$ & \\
\hline
\end{tabular}

Note: N, Sample; M, Sample Mean; SD, Standard Deviation; F, F-Statistics; $\rho$, significance level

\section{Discussion and conclusion}

To innovate whether in the organization's products, processes or market propositions, adequate attention is required to be given to the firm's human capital. This is because innovations are purely products of human activities in form of new ideas, prototypes, concepts, and so on. It is therefore of pertinent importance that firms seeking to gain and maintain competitive advantage must first and foremost look inward to develop and manage human assets. Interestingly, globalization and its resulting demand for talents have exerted enormously pressure on organizations to invest more in attracting and retention talented individuals to their firms as this is the only guaranteed means of imitable competitive advantage (Schuler et al., 2011). With such demands, firms are constantly trying to develop recipe and model for survival and sustainable success. Baring this in mind, this study set out to develop and test an empirical model that investigated the influence firm's talent management systems on their product, process and market innovation in the banking context. Following the objective of the study, three hypotheses were proposed. First, it was proposed that talent management has a positive impact on product innovation. The findings of this study has provided support for this hypothesis which by implication suggests that product innovation or the ability of banks to produce new products is directly related with their orientation towards talent management. Since human capital theory emphasizes the dependences of organization success on its investment on human capital (relational capital) and social exchange theory provides foundation for exchange relationships that often results in performance that yields economic benefits, it is expected that talent management which guarantees high performing individuals with the right benefits will propel such employees to innovate and deliver new products for the firm. This finding is consistent with the view of Beaverstock (2018) who also found that firm's organizational excellence requires the incorporation of talent management as a strategic tool for organization success. Even more, talent management was also found to increase employees' proactiveness which is also essential for product innovation (McDonnell et al., 2017). Studies also supports that crafting talent management programs is crucial for people in crafting the individuals' choice for the employer, increases the employer attractiveness and then in achieving greater talent commitment (Da Motta Veiga \& Turban, 2018; Ewerlin, 2013). As such, talent management fuels the individual's energy and dedication to performing at optimum level which will include patenting new products to their credit.

Talent management therefore based on the finding of this study predicts banks' readiness for product innovation. Because product innovation requires the new product to contain some degree of novelty, McGregor's theory X and Y suggest that talented employee will take initiative to create unique features, attributes and quality in products that symbolizes their individual contribution to business performance. Secondly, this study proposed that talent management has a positive impact on process innovation. Data analysis illustrates that the relationship was significant. It thus, implies that talent management is not only precursory to the result in forms of product innovation but also contributes significantly to the processes by which products are produced. As prior studies have reiterated, innovation is primarily a human creation as it requires the inputs from human assets of the firm to bring about innovation. Specifically, this finding implies that firms that attract and retain talented employees through appropriate employer attraction through their unique aspects of employment offerings will be able to easily harness their employees' capabilities in developing new and novel processes to creating and delivering business performance. This finding in line with employer attraction theory suggest that when firms adopt employer branding as a strategic tool, company's efforts to communicate to existing (internal branding) and prospective staff (external branding) about why this company is a desirable place to work (Lloyd, 2002; Dell \& Hickey, 2002) genuinely attracts talent to the firm thereby eliciting their commitment to the organization and its processes and methods. Further, organization's reputation is a core asset in 
employer branding which implies that before the talent decides to be part of the organization, they are aware of the nature of the processes and mode of operations of the firm and are willing to be a meaning part of it hence a tangible motivation to contribute innovatively to the organization's processes (Barrow \& Mosley, 2011).

Thirdly, the study proposed that talent management positively impacts firm's market innovation. As expected, the result of the study also supported this proposition which by implication means that firms with effective talent management systems or practices are better positioned to identify and apply information from the market that will offer opportunity of novel market entrance. This is important for firms as the intensity of competition in the business world now requires that firms seize every opportunity available to edge out their competition. With talent management in place, firms have the required resources to better serve their target market thereby improving their earning capacity and profitability. This finding is in congruence with empirical findings from prior studies on market orientation (Ho et al., 2018). When this finding is interpreted in the light of human capital theory, we will see that the structural capital of the organization also comes to bears as management and use of knowledge resources of the talents within the organization is essential in taking advantage of the opportunities present in the market or the marketplace. As such, talent management is a must for firm that must succeed in the current day market settings.

Fourth, this study diagnosed and compared several demographic variables with talent management. At the end, only organizational tenure proved to differ in regard to talent management, where the highest level of engagement and willingness to deploy talent management practices have an experience of (10) to (15) years. Prior scholars have argued that talent management is closely aligned with human capital more specifically, the intellectual capital of employees (Tarique, \& Schuler, 2010). The finding in this project echoed the assumptions of Cappelli and Keller (2017), that is having few stars helped investment banks increase performance. The present finding not only validates their arguments, but also extends the validity of this claim to the Jordan, a non-Western work setting.

Fifth, this study also diagnosed and compared several demographic variables with product, process, and marketing innovation. The variables subsume gender, age, organizational tenure, education and bank type. None of the associations were significant except organizational tenure that differs significantly on product, process and marketing innovation. This finding implies that product, process and marketing innovations are dependent on organizational tenure or work experience. This is consistent with Cucculelli (2018), who argued that "high innovative activity is mainly driven by the new CEO's innovation propensity, which is strictly dependent on organizational tenure". Although the outcome shows that organizational tenure is a key indicator for product, process and marketing innovations, but as the tenure increases product, process and marketing innovations may due to maturity e.g., promotion to managerial post and age factor, which prior research has shown to affect creativity and innovation in organizations (i.e., Chandler et al., 2000; Schubert \& Andersson, 2013).

\subsection{Limitations and future research directions}

Although current study provides valuable theoretical and practical implications as abovementioned, the implications are conceived with the following limitations in mind. First, this study focused on talent management and its impacts on innovations at large but failed to consider the medium through which the services of talented individuals are acquired as this may alter the complexion of the result and its implications. Therefore, it will be interesting to know to what degree if at all in impacts the source of talent acquisition will influence the impact of talent management on innovation in banking industry.

Second, although this study focuses on the impact of talent management on comprehensive innovation in the firms as product, process and market innovation were all examined, it failed to consider other contextual factors that may also contribute to the relationship such as human resource investment, organizational culture and management orientation. Future studies may optimize the current model by introducing a mediating or moderating variable to understand how such variable will yield increased benefit for both practitioners and academia (Brik et al., 2011; Cooke, Saini, \& Wang, 2014; Sidani \& Al Ariss, 2014).

\subsection{Conclusions}

To conclude, the purpose of this study was to understand how the talent management in banks impacts on the firm's product, process and market innovation. By investigation the relationship of talent management and firm innovation using the foundational theories of social exchange, human capital, employer attraction and McGregor's X and Y hypotheses, the study contributes to literature and practice as it not only extends the studies on talent management but also provides recommended action steps for managers that will guide them to sustain competitive advantage. Essentially, firms can only innovate when they have mastered the acts of talent management. In turn, the resulting product, process and market innovation of such firms will be novel and serves as the basis for competitive edge as such innovation are embedded in human assets and cannot be imitated.

\section{References}

Abou-Moghli, A. A., Al Abdallah, G. M., \& Al Muala, A. (2012). Impact of innovation on realizing competitive advantage in banking sector in Jordan. American Academic \& Scholarly Research Journal, 4(5), 1. 
Aksoy, H. (2017). How do innovation culture, marketing innovation and product innovation affect the market performance of small and medium-sized enterprises (SMEs)?. Technology in Society, 51, 133-141.

Barrow, S., \& Mosley, R. (2011). The employer brand: bringing the best of brand management to people at work (Reprinted. ed.). Chichester [u.a.]: Wiley.

Baum, M., \& Kabst, R. (2014). The effectiveness of recruitment advertisements and recruitment websites: Indirect and interactive effects on applicant attraction. Human Resource Management, 53(3), 353-378.

Beaverstock, J. (2018). New insights in reproducing transnational corporate elites: the labour market intermediation of executive search in the pursuit of global talent in Singapore. Global Networks, 18(3), 500-522.

Benner, M. J., \& Tushman, M. L. (2003). Exploitation, exploration, and process management: The productivity dilemma revisited. Academy of Management Review, 28(2), 238-256.

Bos, J., Kolari, J., van Lamoen, R. (2012). Competition and innovation: Evidence from financial services. Journal of Banking and Finance, 37(5), 1590-1601.

Brik, A. Ben, Rettab, B., \& Mellahi, K. (2011). Market orientation, corporate social responsibility, and business performance. Journal of Business Ethics, 99(3), 307-324.

Caner, T., \& Tyler, B. B. (2013). Alliance portfolio R\&D intensity and new product introduction. American Journal of Business, 28(1), 38-63.

Cappelli, P., \& Keller, J. R. (2017). The historical context of talent management. The Oxford handbook of talent management, 23-42.

Central Bank of Jordan. (2018). Banking Sector Directory. Available at http://www.cbj.gov.jo/Pages/viewpage.aspx?pageID=307 (accessed 10 May 2018).

Chandler, G. N., Keller, C., \& Lyon, D. W. (2000). Unraveling the determinants and consequences of an innovation-supportive organizational culture. Entrepreneurship Theory and Practice, 25(1), 59-76.

CIPD (2006). Talent Management: Understanding the dimensions. London: CIPD.

Cooke, F. L., Saini, D. S., \& Wang, J. (2014). Talent management in China and India: A comparison of management perceptions and human resource practices. Journal of World Business, 49(2), 225-235.

Crema, M., \& Verbano, C. (2016). Managing Intellectual Capital in Italian Manufacturing SMEs. Creativity and Innovation Management, 25(3), 408-421.

Cucculelli, M. (2018). Firm age and the probability of product innovation. Do CEO tenure and product tenure matter? Journal of Evolutionary Economics, 28(1), 153-179.

Da Motta Veiga, S. P., \& Turban, D. B. (2018). 18 Who Is Searching for Whom? Integrating Recruitment and Job Search Research. The Oxford Handbook of Job Loss and Job Search, 311.

Dell, D., \& Hickey, J. (2002). Sustaining the Talent Quest: Getting and Keeping the Best People in Volatile Times [Research Report]. New York: The Conference Board.

Deshpandé, R., Farley, J. U., \& Webster Jr, F. E. (1993). Corporate culture, customer orientation, and innovativeness in Japanese firms: A quadrad analysis. The Journal of Marketing, 57(1), 23-37.

Drucker, P. (2001). The next society. The Economist

Eisenberger, R., Cotterell, N., \& Marvel, J. (1987). Reciprocation ideology. Journal of Personality and Social Psychology, 53(4), 743.

Elrehail, H., Emeagwali, O. L., Alsaad, A., \& Alzghoul, A. (2018). The impact of transformational and authentic leadership on innovation in higher education: the contingent role of knowledge sharing. Telematics and Informatics, 35(1), 55-67.

Ewerlin, D. (2013). The influence of global talent management on employer attractiveness: An experimental study. German Journal of Human Resource Management, 27(3), 279-304.

Fornell, C., \& Larcker, D., (1981). Evaluating structural equation models with unobservable and measurement error. Journal of Marketing Research, 18(1), 39-50.

Gergen, K. J. (1969). The psychology of behavior exchange. Oxford, England: Addison-Wesley.

Gouldner, A. W. (1960). The norm of reciprocity: A preliminary statement. American Sociological Review, $161-178$.

Hair, J.F., Ringle, C.M., \& Sarstedt, M. (2013). Partial least squares structural equation modeling: rigorous apps, better results and higher acceptance. Long Range Planning, 46(1/2), 1-12.

Henseler, J., Ringle, C.M., \& Sarstedt, M. (2015). A new criterion for assessing discriminant validity in variance-based structural equation modeling. Journal of Academy of Marketing Science, 43(1), 115-135.

Ho, K. L. P., Nguyen, C. N., Adhikari, R., Miles, M. P., \& Bonney, L. (2018). Exploring market orientation, innovation, and financial performance in agricultural value chains in emerging economies. Journal of Innovation \& Knowledge, 3(3), 154-163.

Iles, P., Chuai, X., \& Preece, D. (2010). Talent Management and HRM in Multinational companies in Beijing: Definitions, differences and drivers. Journal of World Business, 45(2), 179-189.

Jayaraman, S., Talib, P., \& Khan, A. F. (2018). Integrated Talent Management Scale: Construction and Initial Validation. SAGE Open, 8(3).

Johne, F., \& Harborne. P. (1985). How Large Commercial Banks Manage Product Innovation. International Journal of Bank Marketing, 3(1), 54-71.

Kiiyuru, K. D. (2014). Effects of innovation strategies on performance of commercial banks in Kenya. School of Business, University of Nairobi.

Kline, R.B. (2015). Principles and practice of structural equation modeling (4th ed.). New York: Guilford Publications. 
Kucherov, D., \& Zavyalova, E. (2012). HRD practices and talent management in the companies with the employer brand. European Journal of Training and Development, 36(1), 86-104.

Lewis, R. E., \& Heckman, R. J. (2006). Talent management: A critical review. Human Resource Management Review, 16(2), $139-154$.

Lievens, F., \& Slaughter, J. E. (2016). Employer image and employer branding: What we know and what we need to know. Annual Review of Organizational Psychology and Organizational Behavior, 3, 407-440.

Lloyd, S. (2002). Branding from the Inside Out. Business Review Weekly, 24(10), 64-66.

MacKenzie, S. B., Podsakoff, P. M., \& Podsakoff, N. P. (2011). Construct measurement and validation procedures in MIS and behavioral research: Integrating new and existing techniques. MIS Quarterly, 35(2), 293-334.

McDonnell, A., Collings, D. G., Mellahi, K., \& Schuler, R. (2017). Talent management: a systematic review and future prospects. European Journal of International Management, 11(1), 86-128.

Morley, M. J., Scullion, H., Collings, D. G., \& Schuler, R. S. (2015). Talent management: A capital question. European Journal of International Management, 9(1), 1-8.

Perrewe, P. L., Hochwarter, W. A., Rossi, A. M., Wallace, A., Maignan, I., Castro, S. L., \&Van Deusen, C. A. (2002). Are work stress relationships universal? A nine-region examination of role stressors, general self-efficacy, and burnout. Journal of International Management, 8(2), 163-187.

Podsakoff, P., MacKenzie, S., Lee, J., \& Podsakoff, N. (2012). Sources of method bias in social science research and recommendations on how to control it. Annual Review of Psychology, 63, 539-69.

Richter, N.F., Cepeda Carrión, G., Roldán, J.L., \& Ringle, C.M. (2016). European Management Research Using Partial Least Squares Structural Equation Modeling (PLS-SEM). European Management Journal 34(6), 589-597.

Rotolo, C. T., Church, A. H., Adler, S., Smither, J. W., Colquitt, A. L., Shull, A. C., ... Foster, G. (2018). Putting an End to Bad Talent Management: A Call to Action for the Field of Industrial and Organizational Psychology. Industrial and Organizational Psychology, 11(2), 176-219.

Schubert, T., \& Andersson, M. (2013). Old is gold? the effects of employee age on innovation and the moderating effects of employment turnover (No. 2013/29). Lund University, CIRCLE-Center for Innovation, Research and Competences in the Learning Economy.

Schuler, Jackson, S. E., \& Tarique, I. (2011). Global talent management and global talent challenges: Strategic opportunities for IHRM. Journal of World Business, 46(4), 506-516.

Scullion, H., \& Collings, D. (2011). Global talent management. New York, NY: Routledge.

Sidani, Y., \& Al Ariss, A. (2014). Institutional and corporate drivers of global talent management: Evidence from the Arab Gulf region. Journal of World Business, 49(2), 215-224.

Sivertzen, A.-M., Nilsen, E. R., \& Olafsen, A. H. (2013). Employer branding: employer attractiveness and the use of social media. Journal of Product \& Brand Management, 22(7), 473-483.

Škerlavaj, M., Song, J.H., Lee, Y. (2010). Organizational learning culture, innovative culture and innovations in South Korean firms. Expert Systems Application, 37 (9), 6390-6403.

Sok, P., O’Cass, A., \& Sok, K. M. (2013). Achieving superior SME performance: Overarching role of marketing, innovation, and learning capabilities. Australasian Marketing Journal (AMJ), 21(3), 161-167.

Sparrow, P. R., \& Makram, H. (2015). What is the value of talent management? Building value-driven processes within a talent management architecture. Human Resource Management Review, 25(3), 249-263.

Story, J. (2007). Human Resource Management: A Critical Text, 3rd ed.. London: Thomson Learning.

Tarique, I., \& Schuler, R. S. (2010). Global talent management: Literature review, integrative framework, and suggestions for further research. Journal of World Business, 45(2), 122-133.

Tatoglu, E., Glaister, A. J., \& Demirbag, M. (2016). Talent management motives and practices in an emerging market: A comparison between MNEs and local firms. Journal of World Business, 51(2), 278-293.

Tipu, S. A., (2011). Academic publications on innovation management in banks (1998-2008): A research note. Journal of Innovation Organization \& Management, 13(2), 236-260.

Yen, Y.F. (2013). The impact of bank's human capital on organizational performance: How innovation influences performance. Innovation, 15(1), 112-127.

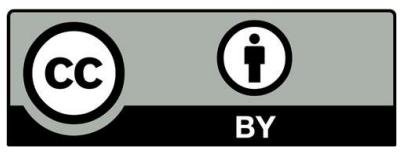

(C) 2020 by the authors; licensee Growing Science, Canada. This is an open access article distributed under the terms and conditions of the Creative Commons Attribution (CC-BY) license (http://creativecommons.org/licenses/by/4.0/). 